\title{
СУЧАСНИЙ АЛГОРИТМ МЕДСЕСТРИНСЬКОГО ДОГЛЯДУ ЗА ХВОРИМИ НА БРОНХІАЛЬНУ АСТМУ
}

\author{
В. І. Лях, Р. М. Ляхович, Б. В. Дорошенко, Я. М. Кіцак \\ ДвНЗ «Тернопільський державний медичний університет \\ імені І. Я. Горбачевського МОЗ Украӥни»
}

\begin{abstract}
У статті розглянуто проблему широкого поширення захворювань дихальної системи, а саме - бронхіальної астми. Окрім етіології, клінічного перебігу, також висвітлено особливості сучасної діагностики та лікування цієї нозології на основі поглибленого аналізу наукових та інших літературних даних стосовно особливостей перебігу цього захворювання, особистого спілкування та спостереження за окремою пацієнткою розробити власний алгоритм комплексного медсестринського догляду за хворими з цією патологією.
\end{abstract}

\section{CURRENT ALGORITHM OF NURSING CARE FOR PATIENTS WITH BRONCHIAL ASTHMA}

\author{
V. I. Liakh, R. M. Liakhovych, B. V. Doroshenko, Ya. M. Kitsak
}

\section{Horbachevsky Ternopil State Medical University}

\begin{abstract}
The article is devoted to the problem of widespread diseases of the respiratory system, namely, bronchial asthma. In addition to the etiology, clinical course, the features of modern diagnostics and treatment of this nosology are also covered on the basis of in-depth analysis of scientific and other literary data concerning the peculiarities of the course of this disease, personal communication and observation of the individual patient to develop their own algorithm for complex nursing care for patients with this pathology.
\end{abstract}

Вступ. Бронхіальна астма (БА) є однією з найпоширеніших нозологій. Згідно з даними Світової організації здоров'я, на бронхіальну астму хворіють 100-150 млн людей. Загалом близько 6 \% дорослої популяції хворіють на БА і 180 млн людей у світі помирає з приводу ускладнень цієї патології кожного року. Із року в рік захворюваність на БА тільки зростає, поширеність у країнах Європи становить 2-7 \% серед дорослого населення, що в кінцевому результаті призводить до втрати працездатності, інвалідизації пацієнтів, великих витрат на лікування, їх психологічного дискомфорту тощо.

Все це зумовлює необхідність пошуку якісного медичного спостереження за пацієнтами з такою категорією захворювань, де особлива роль належить якісному комплексному медсестринському догляду. Через це, актуальною проблемою вважають не тільки оцінку загальної характеристики хвороби, ай сучасну класифікацію та етіологічні чинники БА. На сьогодні патогенез та основні клінічні прояви БА мають свої особливості, а проблема реабілітації пацієнтів із такою

(c) В. І. Лях, Р. М. Ляхович, Б. В. Дорошенко, Я. М. Кіцак, 2019 патологією є ще не до кінця висвітленою. Мета досліджень - покращити загальний стан хворих, якість та спосіб їхнього життя [1-8].

Основна частина. Сучасна класифікація та етіологічні чинники бронхіальної астми

Загалом існує ціла низка класифікацій БА. Водночас на сьогодні у науково-практичних медичних колах використовують сучасну універсальну класифікацію БА, яка включає такі патологічні стани:

1) переважно алергічну астму (алергічну, атопічну, зовнішню алергічну астму, внутрішню неалергічну aстму);
2) змішану;
3) неуточнену;
4) астматичний стан.

Існує класифікація БА за їі клінічними проявами. Це захворювання класифікують за ступенем тяжкості перебігу та результатами аналізу комплексу клінічних та функціональних ознак бронхіальної обструкції, а також відповіді на лікування в період між нападами [9]. Оцінку змін функціональних показників для ви- 
значення тяжкості захворювання проводять в період відсутності епізодів експіраторної задишки. Саме через це класифікація БА, згідно зі ступенем тяжкості, особливо важлива при вирішенні питання ведення захворювання для первинної оцінки стану пацієнта. Згідно з цією класифікацією виділяють:

1) інтермітуючий (епізодичний) перебіг;

2) персистуючий (постійний) перебіг: за ступенем тяжкості: легкий, середній, тяжкий.

\section{Етіологія бронхіальної астми}

Виділять такі групи етіологічних факторів БА:

1. Внутрішні:

1.1. Генетичні: гени, що кодують схильність до атопії; гени, що кодують гіперреактивність бронхів.

1.2. Ожиріння.

1.3. Стать (після 14 років частіше хворіють жінки).

2. Зовнішні:

2.1. Алергени приміщень: домашні кліщі, тварини з хутряним покривом (собаки, кішки, миші), таргани, гриби; зовнішні: пилок, гриби (насамперед плісняві та дріжджові).

2.2. Інфекції (переважно вірусні - респіраторно синтиціальний вірус (РСВ), парагрип).

2.3. Професійні алергени.

2.4. Куріння: пасивне, активне.

2.5. Забруднення атмосфери або повітря приміщень.

2.6. Харчування.

\section{Патогенез бронхіальної астми}

Сучасна концепція патогенезу БА розглядає його як характерний специфічний запальний процес, який призводить до розвитку бронхіальної обструкції і підвищення гіперреактивності бронхів у відповідь на різні провокуючі фактори (імунологічні, нейрогенні, фізичні, хімічні). Характерною ознакою цього запалення $є$ підвищений вміст активованих клітин (еозинофілів, опасистих клітин, нейтрофілів, лімфоцитів і т. д.) у слизовій оболонці бронхіального дерева і його просвіті, потовщення ретикулярного шару базальної мембрани альвеол. Під впливом антигенної (алергенної) дії в організмі розвивається стан сенсибілізації, який проявляється появою клітин, чутливих до цього алергену або накопичення антитіл (IgE, IgG, IgM), специфічних до нього (первинна відповідь) [10-15].

Основні клінічні симптоми та прояви бронхіальної астми

Типовими клінічними симптомами БА є епізодичне свистяче дихання, утруднене на видиху; кашель, більше вночі та при фізичному навантаженні; епізодичні та свистячі хрипи в легенях; повторна скованість грудної клітки. Ці симптоми здебільшого погіршуються вночі та пробуджують хворого, а також виникають та прогресують при фізичному навантаженні, вірусній інфекції, впливі різного роду алергенів (харчових, свійських тварин, домашнього пилу, пилку рослин), курінні, перепаді зовнішньої температури, сильних емоціях (плачу, сміху), дії хімічних аерозолів, прийманні деяких ліків (нестероїдних протизапальних, $\beta$-блокаторів).

основні діагностичні критерії бронхіальної астми

\section{Клінічні:}

1. Типові повторні напади ядухи, переважно у нічний та вранішній час.

2. Експіраторна задишка.

3. Симетричне здуття грудної клітки, особливо у верхніх відділах, втягування міжреберних проміжків, у тяжких випадках - трахеостернальна ретракція.

4. Коробковий відтінок перкуторного тону, або коробковий тон.

5. Дифузні сухі свистячі хрипи на тлі жорсткого або послабленого типу дихання.

\section{Анамнестичні:}

1. Періодичність виникнення астматичних симптомів, часто сезонний характер загострень астми.

2. Супутні прояви атопії (алергічний риніт, атопічний дерматит, дермореспіраторний синдром, харчова алергія), які передують початковим ознакам астми.

3. Обтяжений сімейний анамнез.

\section{Функціональні:}

1. Обструктивний тип вентиляційних порушень.

2. Зворотність порушень бронхіальної прохідності.

3. Наявність гіперреактивності бронхів за даними спірометрії, пневмотахометрії, велоергометрії з використанням провокаційних проб із бронхоконстрикторами (гістамін, метахолін, ацетилхолін, гіпертонічний розчин натрію хлориду) або з фізичним навантаженням.

\section{Лабораторно-діагностичні:}

1. Підвищений рівень еозинофілів у крові.

2. Алергологічні категорії:

а) підвищений рівень еозинофілів у харкотинні та носовому слизі;

б) підвищений рівень загального імуноглобуліну E (IgE) у сироватці крові;

в) позитивні результати скарифікаційних шкірних проб (прик-тестів), які свідчать про атопічний статус;

г) підвищені рівні алергеноспецифічних IgE у сироватці крові.

Діагноз БА встановлюють за наявності у хворого клінічних та функціональних проявів. Характерна добова та сезонна варіабельність симптомів. 


\section{Ускладнення БА:}

- легеневе серце (гостре, підгостре, хронічне);

- хронічна емфізема легень;

- пневмосклероз;

- сегментарний або полісегментарний ателектаз легень;

- інтерстиціальна, медіастинальна або підшкірна емфізема;

- спонтанний пневмоторакс;

- астматичний стан;

- неврологічні ускладнення (бетолепсія - епізоди короткочасної втрати свідомості на висоті кашлю або нападу при тяжкій астмі; судомний синдром, гіпоксична кома);

- ендокринні розлади (при гормонозалежній астмі, тривалій системній терапії ГКС - синдром ІценкаКушинга, трофічні порушення, міопатичний синдром, остеопороз, стероїдний діабет тощо) [16-18].

\section{Лікування бронхіальної астми}

Медикаментозну терапію хворих на БА проводять із використанням різних шляхів введення препаратів - інгаляційного, перорального та парентерального. Найбільшу перевагу має інгаляційний шлях, що забезпечує виражену місцеву дію лікарських засобів у легенях, не спричиняє небажаної системної дії, дає можливість прискорити позитивний ефект лікування за рахунок менших доз ліків. Згідно з розробленими міжнародними рекомендаціями, на сьогодні загальновизнаним $\in$ ступінчастий підхід до фармакотерапії хворих на БА.

Ступінь I - інтермітуюча бронхіальна астма. Лікування проводять симптоматичне, за потреби: інгаляційні $\beta_{2}$-агоністи короткої дії (сальбутамол, фенотерол, вентолін) по 1-2 інгаляції 2-3 рази у разі необхідності (за наявності симптомів) - перший вибір. Рекомендовано профілактичне приймання перед фізичним навантаженням або перед ймовірним впливом алергену. Якщо $є$ потреба в бронхолітиках більше одного разу на тиждень протягом більше 3 місяців або коли функція зовнішнього дихання в періоди між загостреннями не повертається до норми - необхідно переглянути ступінь тяжкості, $\epsilon$ висока ймовірність, що у пацієнта має місце легка персистуюча БА.

Ступінь II - легка персистуюча бронхіальна астма. Рекомендують лікування - симптоматичну терапію плюс один контролюючий засіб: щоденне регулярне лікування протизапальними засобами для досягнення і підтримання контролю БА. Перевагу надають призначенню інгаляційних глюкокортико- стероїдів (ГКС), а саме беклозон-еко, бекламетазон, будесонід, флутиказон у низьких добових дозах (200500 мкг). Добову дозу призначено на одне приймання.

Альтернативні контролюючі медикаменти: кромони, модифікатори лейкотриєнів - менш ефективні, ніж інгаляційні ГКС; пролонгованої дії ксантини - мають слабку протизапальну дію, застосування пов'язано із значними побічними ефектами.

Ступінь III - персистуюча бронхіальна астма середньої тяжкості. Проводять симптоматичну терапію плюс один або два контролюючі засоби. Щоденне регулярне лікування протизапальними засобами для досягнення і підтримання контролю БА.

Рекомендують поєднане приймання інгаляційних ГКС (беклозон-еко, беклофорт, бекламетазон, будесонід, флутиказон) у низьких дозах (800-1000 мкг) та інгаляційних $\beta_{2}$-агоністів пролонгованої дії (сальметерол, формотерол) по 50 мкг (1 доза) 1-2 рази на добу як в окремих пристроях, так і у фіксованій комбінації. Фіксована комбінація в одній лікарській формі інгаляційного ГКС й інгаляційного $\beta_{2}$-агоніста пролонгованої дії покращує комплаєнс (зручний шлях доставки ліків, зазвичай кращі фармакоекономічні показники). Такими препаратами є симбікорт (будесонід+формотерол) 160/4,5 мкг, серетид (сальметерол+флутиказон) 50/250 мкг або 25/125 мкг. Необхідно пам'ятати, що $\beta_{2}$-агоністи пролонгованої дії в монотерапії без інгаляційного ГКС не призначають.

Інший вибір - призначення середніх - високих добових доз (500-800 мкг до 1000 мкг) інгаляційних ГКС або комбінація інгаляційних ГКС у низьких дозах із модифікаторами лейкотриєнів; або з ксантинами пролонгованої дії (більший ризик розвитку побічних ефектів).

Ступінь IV - тяжка персистуюча бронхіальна астма. Лікування - симптоматична терапія плюс два або більше контролюючих засобів. Переваги має поєднане приймання інгаляційних ГКС у високих добових дозах (беклозон-еко, беклофорт, бекламетазон, будесонід, флутиказон) (1000-2000 мкг) в комбінації 3 інгаляційними $\beta_{2}$-агоністами пролонгованої дії (2550 мкг), можливо в одній лікарській формі.

При недостатній ефективності цієї комбінації показане додаткове призначення модифікаторів лейкотриєнів та/або ксантинів пролонгованої дії.

У разі необхідності при тяжкій неконтрольованій БА з щоденним обмеженням активності з частими загостреннями додатково довготривало призначають пероральні ГКС у мінімально можливих для досягнення ефекту дозах. Якщо пацієнтів переводять 3 
приймання оральних ГКС на високі дози інгаляційних ГКС, необхідно ретельно моніторувати ознаки надниркової недостатності.

При тяжкій БА з високим рівнем IgЕ ефективним $\epsilon$ призначення препаратів рекомбінантних людських антитіл до IgE [19-20].

Фізична реабілітація - одна з провідних ланок у комплексному нефармакологічному лікуванні БА

Зазвичай комплекс немедикаментозних заходів у лікуванні БА складається з низки процедур та, як правило, застосовується для пацієнтів, які подолали гострий період захворювання. Лікувальну фізичну культуру (ЛФК) призначають у період між нападами за умови задовільного загального стану хворого. ЛФК протипоказана у разі наявності астматичного статусу, дихальної та серцевої недостатності з декомпенсацією функцій цих систем. Використовують спеціальні дихальні вправи з вимовою на повільному видиху визначених звуків, із дозованими затримками дихання, що сприяють поліпшенню вентиляційної функції легень і попереджають напад бронхіальної астми.

Санаторно-курортне лікування. У фазі ремісії рекомендують лікування на кліматичних курортах із сухим і теплим кліматом, у санаторіях, розташованих у лісових зонах, в умовах середньогір'я (Кисловодськ, Нальчик, Гірський Урал та ін.), на Південному березі Криму. Позитивні результати дає лікування у місцевих заміських санаторіях, розташованих поблизу місць постійного проживання, оскільки таке лікування не вимагає адаптації до нових кліматичних умов [21].

Прогноз для життя - відносно задовільний, для одужання - несприятливий. Наслідком розвитку захворювання $\epsilon$ прогресуюча дихальна недостатність.

Власні дослідження. Проведено комплексний аналіз історії хвороби у пацієнтки 59 років із діагнозом: тяжка персистуюча бронхіальна астма, неконтрольований перебіг ДН II та супутньою патологією: Хронічне обструктивне захворювання легень ІІ ступеня. Хронічний панкреатит. Гіпертонічна хвороба, 2 стадія, 2 ступінь, ССР ІІІ. СН І. Аліментарно-конституційне ожиріння III ступеня. Хронічний калькульозний холецистит. Аутоімунний тиреоїдит.

Медсестринські рекомендації із догляду за пацієнткою

Базовими напрямками профілактики загострень бронхіальної астми у нашої пацієнтки є запобігання контакту з алергенами, зокрема щоденне вологе прибирання житла, припинення контакту із неспецифічними подразнювальними факторами навколишнього середовища (вихлопні гази, тютюновий дим), раціональне харчування, адекватне застосування необхідних медичних засобів, своєчасна санація вогнищ хронічної інфекції, активний спосіб життя, загартовування, заняття фізкультурою і спортом.

Рекомендовано для пацієнтки такі варіанти алгоритму ЛФК:

1. Вдосконалення (нормалізація) вищих регуляторних механізмів ЦНС.

2. Покращення психічних процесів - вольових, відчуття, сприйняття та ін.

3. Вироблення та закріплення навичок самоконтролю, саморегуляції, керування диханням, розслаблення м'язів.

4. Вдосконалення діяльності та збільшення функціональних можливостей дихальної системи (збільшення жЄЛ, легеневої вентиляції, екскурсії грудної клітки і передньої черевної стінки (діафрагми), покращення газообміну, укріплення м'язів, що беруть участь у процесі дихання).

5. Покращення акту дихання (ритму, глибини, плавності).

6. Загальне зміцнення та загартовування організму. Підвищення опірності до простудних захворювань.

\section{Дієта, рекомендована для хворої}

Хворій рекомендоване значне споживання продуктів, що містять магній. Це, в свою чергу, призводить до зниження гіперреактивності бронхів та покращення функції легень. Також їй рекомендоване достатнє споживання вітамінів C, Е і селену, значної кількості свіжих фруктів і овочів. Дисбаланс кишкової флори у таких хворих, зокрема у нашої пацієнтки, асоціюється з високим ризиком розвитку алергії. Враховуючи надлишкову масу тіла, виявлено чіткий зв'язок між збільшенням індексу маси тіла і симптомами астми. Тому рекомендуємо хворій зменшити енергетичну цінність щоденного раціону харчування за рахунок вуглеводів, особливо його легкозасвоювальних форм.

Висновки. 1.У роботі нам вдалося на основі аналізу історії хвороби виокремленої пацієнтки розробити комплексний алгоритм медсестринського догляду за конкретною хворою, і маємо надію, що ця методика може бути успішно застосована для інших пацієнтів із цією патологією.

2. Завершена робота стосується розробки прогресивних технологій медсестринського догляду за пацієнтами з тяжким перебігом БА з урахуванням процесу реабілітації, який націлений на відновлення повної, а в особливо тяжких випадках - часткової працездатності. 
3. У нашій праці проведено обширний аналіз різноманітних літературних даних (вітчизняної, зарубіжної тощо) стосовно цієї патології. На сьогодні це захворювання стоїть в одному ряду з різноманітними серцевими захворюваннями як Хвороба цивілізації XXI століття.

4. 3 огляду на фактори ризику БА, в нашій роботі ми намагалися визначити проблеми, пов'язані з доглядом і реабілітацією хворої, запропонувати нові методи і сучасний погляд на проблеми БА, які наведені нижче в літературі.

5. Зробили опис конкретного випадку (хвора на бронхіальну астму з тяжким персистуючим перебігом).

6. На основі власних спостережень та інформації, отриманої на основі прямого контакту з хворою,

\section{СПИСОК ЛІТЕРАТУРИ}

1. Asthma: symptoms and diagnosis EBM Guidelines 21.3.2017. Latest change 21.3.2017 Paula Kauppi.

2. Pocket guaide of asthma management and prevention, 2018. Global initiative for asthma.

3. Pulmonary function tests EBM guidelines 20.3.2017. Last change 20.3.2017 Anssi R.A. Sovijarvi.

4. Treatment of acute exacerbation of asthma EBM Guidelines 21.3.2017. Last change 21.3.2017 Paula Kauppi.

5. Кубєц Александра Внутрішні хвороби (підручник, заснований на принципах доказової медицини) / Александра Кубєц. - Республіка Польща : Практична медицина, 2018. - 1632 с.

6. Альошина А. Значення засобів фізичної реабілітації, які використовуються в лікуванні хворих на бронхіальну астму / А. Альошина // Збірник наукових праць Волинського національного університету імені Лесі Українки. 2012. - № 3 (19). - 271c.

7. Богданов В. В. Валеологія і реабілітація при бронхолегеневих захворюваннях / В. В. Богданов, С. Н. Попова. - К. : Дія, 2003. - 268 с.

8. Бронхіальна астма : монографія / М. С. Регеда, М. М. Регеда, Л. О. Фурдичко [та ін.]. - 5-те вид., доповн. та перероб. - Львів, 2012. - 147 с.

9. Впровадження діагностичних, прогностичних та лікувальних шкал з внутрішньої медицини у навчальний процес підготовки студентів і лікарів післядипломної освіти : навч. посіб. / [В. І. Денесюк та ін.] ; за ред. проф. В. І. Денесюка, проф. Р. Г. Процюка ; Вінницький національний медичний університет ім. М. І. Пирогова. - К. : Центр ДЗК, 2017. - 167 с.

10. Гішберг Л. С. Профілактика, діагностика, лікування, реабілітація при бронхіальній астмі / Л. С. Гішберг. - М. : СМОЛгИЗ, 2004. - 360 с.

11. Догляд за хворими. Практика : підручник / О. М. Ковальова, В. М. Лісовий. - 3-тє вид., випр. - К. : Медицина, 2015. - 488 c. розробили для неї комплексний медсестринський догляд, який називають тривалою реабілітацією. Все це ґрунтувалося на тлі динамічного спостереження за пацієнткою, ії̈ станом, аналізі наявної медичної документації та співбесід.

Кінцева мета нашої роботи полягала в тому, щоб на основі сучасних літературних даних, інформації, зібраної при безпосередньому спостереженні за пацієнткою, симптоматичним комплексом, аналізом медичної документації, оцінити загальний стан здоров'я пацієнтки і визначити потребу в реабілітації для покращення якості її життя. Маємо сподівання, що наші дослідження та рекомендації будуть корисні для інших пацієнтів із цим захворюванням.

12. Касевич Н. І. Загальний догляд за хворими і медична маніпуляційна техніка : підручник для ВНЗ I-ІІІ рівнів акредитації / Н. І. Касевич, В. І. Литвиненко. -6-те вид. - К. : Медицина, 2014. - 424 с.

13. Іларіонов В. П. Фізична реабілітація при бронхіальній астмі / В. П. Іларіонов ; за ред. проф. С. Н. Попова. М. : ФіС, 2004. - 220 c.

14. Кашуба В. А. Спортивна і клінічна реабілітація при бронхіальній астмі / В. А. Кашуба. - К. : Олімпійська література, 2003. - 260 с.

15. Клінічна пульмонологія / за ред. І. І. Сахарчук. - К. : Книга плюс, 2003. - 368 с.

16. Медицина неотложных состояний: учебник / И. С. Зозуля, А. В. Вершигора, В. И. Боброва и др. ; под ред. И. С. Зозули. - К. : Медицина, 2012. - 696 с.

17. Уніфікований клінічний протокол первинної, вторинної (спеціалізованої) медичної допомоги «Бронхіальна астма» : наказ Міністерства охорони здоров'я України 08 жовтня 2013 р. № 868.

18. Пєшкова О. В. Фізична реабілітація при захворюваннях внутрішніх органів : [навчальний посібник] / О. В. Пєшкова. - Харків: СПДФО Бровін О. В., 2011. - 312 с.

19. Сучасні класифікації та стандарти лікування захворювань внутрішніх органів. Невідкладні стани в терапії. Аналізи. Нормативні показники. Трактування змін / за ред. проф. Ю. М. Мостового. - 25-те вид., змін. та доповн. - К. : Центр ДЗК, 2018. - 792 с.

20. Екстрена медична допомога / М. І. Швед, А. А. Гудима, Р. М. Ляхович [та ін.]. - Тернопіль : Укрмедкнига, 2014. - 420 c.

21. Швед М. І. Основи внутрішньої медицини / М. І. Швед. - Тернопіль : Укрмедкнига, 2018. - 827 с. 